\title{
ANALISIS SURVEY PILIHAN STUDI DAN BIDANG KERJA LULUSAN SMA/SMK DI KALIMANTAN TIMUR
}

\author{
Saiful Ghozi ${ }^{{ }^{*}}$, Ida Suriana ${ }^{2}$, Ramli $^{3}$ \\ 1,3 Jurusan Elektronika Politeknik Negeri Balikpapan \\ ${ }^{2}$ Jurusan Tata Boga Politeknik Negeri Balikpapan \\ *e-mail:saiful.ghozi@poltekba.ac.id
}

\begin{abstract}
The studiy on the potential of prospective students is needed, so that direction of the new course development in State Polytechnic of Balikpapan can be targeted according to the existing potential. This study aims to determine the study orientation during post-graduate of Senior High School student in East Kalimantan. The orientation includes: choice of courses, the city as the purpose of study, and also the work field orientation which become the interest of senior high school student in East Kalimantan. From the results of research there are several conclusions including: (1) 80\% of graduate students in senior high school oriented to go to college, (2) Majority of graduate students in senior high school interested to study in field of non-engineering, especially in the economic field, (3) the courses that mostly interesting in State Polytechnic of Balikpapan is Finance and Banking Department, (4) areas of work which become the main choice of graduate students in senior high school are banking, governmental (civil servant), and in education. Suggestion from this study is needed to make a socialization and better promotion of the State Polytechnic of Balikpapan to introduce its existence as a state university in East Kalimantan.
\end{abstract}

Keywords : Senior High School, study, work

\begin{abstract}
Abstrak
Kajian tentang potensi calon peserta didik perlu dilakukan sehingga arah pengembangan program studi baru yang ada di Politeknik Negeri Balikpapan dapat terarah sesuai potensi yang ada. Penelitian ini bertujuan untuk mengetahui orientasi studi pasca lulus siswa SLTA di Kalimantan Timur. Orientasi tersebut mencakup : pilihan program studi, kota yang yang menjadi tujuan studi, dan juga orientasi bidang kerja yang diminati siswa lulusan SLTA di Kalimantan Timur. Dari hasil penelitian di dapatkan kesimpulan diantaranya: (1) $80 \%$ siswa lulusan SLTA berorientasi melanjutkan ke perguruan tinggi, (2) mayoritas siswa calon lulusan SLTA berminat kuliah di bidang non rekayasa khususnya dibidang ekonomi, (3) program studi yang paling diminati di Politeknik Negeri Balikpapan adalah prodi Keuangan dan Perbankan, (4) bidang kerja yang menjadi pilihan utama siswa calon lulusan SLTA adalah perbankan, pemerintahan (CPNS ), dan dibidang pendidikan. Saran dari penelitian ini adalah perlunya sosialisasi dan promosi yang lebih baik dari Politeknik Negeri Balikpapan untuk lebih mengenalkan keberadaannya sebagai sebuah perguruan tinggi negeri di Kalimantan Timur
\end{abstract}

Kata kunci : SLTA, study, kerja

\section{Pendahuluan}

Jumlah kantor layanan jasa keuangan baik bank maupun non bank di Kalimantan timur meningkat pesat sebagai konsekuensi laju pertumbuhan industri layanan jasa keuangan. Tercatat banyak kantor sebanyak 470 di akhir tahun 2011, menjadi 599 kantor di akhir tahun 2013 [1]. Perkembangan tersebut tentu sejalan dengan kebutuhan tenaga kerja.
Politeknik Negeri Balikpapan didalam proses pengembangannya perlu melaksanakan survei dan analisis potensi calon mahasiswa yang potensial menjadi peserta didik dibidang kerja yang dibutuhkan oleh pasar kerja. Sehingga Politeknik Negeri Balikpapan dapat melaksanakan pengembangan diri yang baik dan terarah sesuai dengan potensi yang ada dilapangan. 
Penelitian ini bertujuan untuk mengetahui (1) sebaran minat siswa SMA/SMK dalam menentukan keberlanjutan pendidikan setelah lulus SMA/SMK, (2) sebaran minat siswa SMA/SMK dalam menentkan bidang pekerjaan yang ditekuni, (3) berapa besar potensi lulusan SMA/SMK/MA yang berminat kerja dibidang perbankan dan keuangan, dan (4) berapa besar potensi lulusan SMA atau SMK di Kalimantan Timur yang berminat melanjutkan studi di program studi Keuangan dan Perbankan

Hasil dari penelitian ini diharapkan akan memperkuat pijakan ilmiah Politeknik Negeri Balikpapan dalam rangka pembukaan program studi baru yaitu program studi diploma III Perbankan dan Keuangan.

\subsection{Perkembangan Industri Layanan Jasa Keuangan di Kalimantan Timur}

Jumlah bank di Kalimantan Timur setiap tahun mengalami peningkatan yang signifikan. Hal ini menunjukkan perekonomian Provinsi Kalimantan Timur yang berkembang pesat Menurut Badan Pusat Statistik Kalimantan Timur pada tahun 2013, lembaga keuangan di Kalimantan Timur yang berbentuk kantor bank berjumlah 500 unit. Dari 500 unit kantor bank tersebut 177 unit berada di Kota Samarinda, 168 unit di Kota Balikpapan, 37 unit di Kabupaten Kutai Kartanegara, dan 36 unit di Kota Bontang, dan selebihnya menyebar di kabupaten [8].

Berikut data jumlah bank di Kalimantan Timur berdasarkan rincian kantor pusat dan kantor cabangnya;
Tabel 1 Data Jumlah Kantor Bank di Kalimantan Timur tahun 2013

\begin{tabular}{|l|l|l|l|l|l|l|}
\hline No & $\begin{array}{l}\text { Kelompok } \\
\text { Bank }\end{array}$ & KP & KC & KCP & KK & Total \\
\hline 1 & Pemerintah & 0 & 25 & 160 & 26 & 211 \\
\hline 2 & $\begin{array}{l}\text { Pemerintah } \\
\text { Daerah }\end{array}$ & 1 & 15 & 59 & 25 & 100 \\
\hline 3 & $\begin{array}{l}\text { Swasta } \\
\text { Nasional }\end{array}$ & 0 & 66 & 85 & 5 & 156 \\
\hline 4 & $\begin{array}{l}\text { Asing dan } \\
\text { Campuran }\end{array}$ & 0 & 4 & 4 & 0 & 8 \\
\hline 5 & BPR/S & 15 & 6 & 0 & 14 & 35 \\
\hline & Total & 16 & 116 & 116 & 308 & 556 \\
\hline
\end{tabular}

Sumber: Bank Indonesia (2013) [8]

\subsection{Kompetensi SDM Perbankan dan Keuangan}

Berdasarkan data penyerapan tenaga kerja di Kaltim, sektor jasa lebih dominan penyerapannya dibanding sektor lainnya. Diakhir tahun 2013 sektor jasa menjadi yang terbanyak menyerap tenaga kerja dengan $50,3 \%$, diikuti oleh sektor pertanian $26,01 \%$, dan yang terakhir adalah sektor industri sebesar 23,09\% (Sumber BPS Kaltim). Penyerapan ini naik sekitar 2\% dibanding tahun sebelumnya, dan diperkirakan naik diakhir tahun 2014. Perkembangan penyerapan tenaga kerja pada sektor yang lebih rinci dapat dilihat pada tabel berikut :

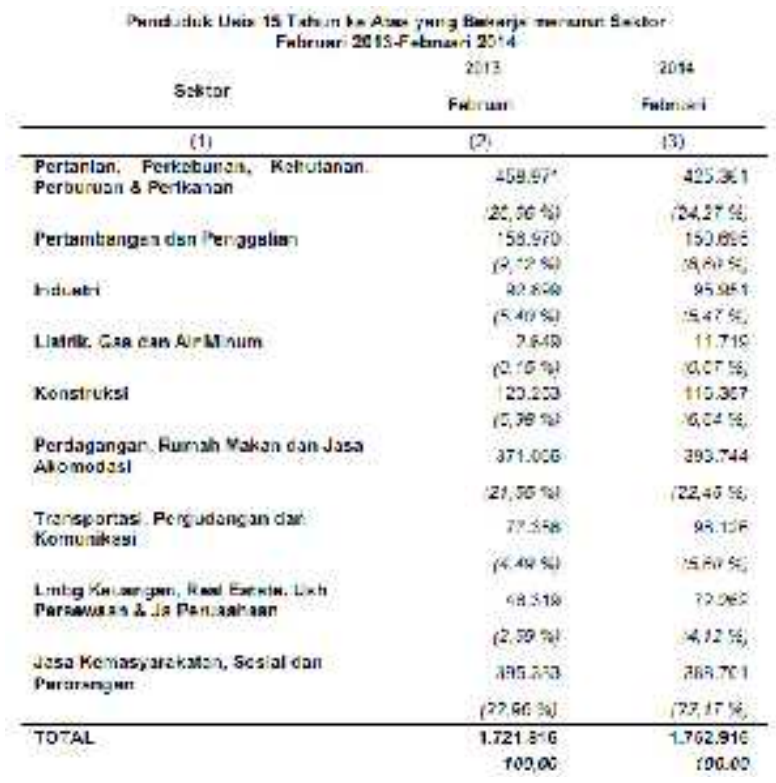

Sumber: Berita Resmi Statistik BPS Kaltim [3]

Terlihat bahwa penyerapan tenaga kerja pada sektor lembaga keuangan, real estate, usaha persewaan, dan jasa 
perusahaan mengalami kenaikan dari 2,69\% dari total pekerja di Kalimantan Timur pada awal tahun 2013 menjadi $4,12 \%$ di awal tahun 2014 . Seiring semakin meningkatnya jumlah kantor bank di Kalimantan Timur serta perkembangan ekonomi yang baik tentu akan dibarengi dengan kebutuhan tenaga terampil dan professional dibidang ekonomi, keuangan, baik bank maupun non bank. Sehingga dibutuhkan layanan pendidikan yang mampu menjawab kebutuhan tersebut.

Politeknik Negeri Balikpapan sebagai salahsatu politeknik yang masih berkembang di Kalimantan Timur memiliki memiliki rencana strategis, salahsatunya yaitu membuka program studi baru yang sesuai dengan karakteristik kebutuhan tenaga kerja di Kalimantan Timur. Dalam rangka itu kajian - kajian dan survai terkait kebutuhan tenaga kerja diperlukan sebagai pijakan ilmiah Politeknik Negeri Balikpapan dalam menentukan arah pengembangannya dibidang pendidikan vokasi. Hasil dari penelitian ini diharapkan akan memperkuat pijakan ilmiah Politeknik Negeri Balikpapan dalam rangka pembukaan program studi baru yaitu program studi diploma III perbankan dan keuangan.

\subsection{Statistik Lulusan SMA/SMK di Kalimantan Timur dan} Keterserapannya di Perguruan Tingggi Berikut disajikan data statistik kelulusan siswa SLTA di Kalimantan Timur.

Tabel 2 Jumlah Lulusan SLTA di Kalimantan Timur

\begin{tabular}{|l|l|}
\hline Tahun & $\begin{array}{l}\text { Jumlah Lulusan } \\
\text { SLTA }\end{array}$ \\
\hline 2013 & 19.046 \\
\hline 2014 & 18.971 \\
\hline 2015 & 22.769 \\
\hline
\end{tabular}

Sumber: BPS Kaltim

Lebih spesifik berikut disajikan data statistik kelulusan siswa SLTA per kabupaten/kota di Kalimantan Timur.
Tabel 3 Jumlah Lulusan SLTA kabupaten/kota di Kalimantan Timur tahun 2014 dan tahun 2015

\begin{tabular}{|l|r|r|}
\hline Kabupaten/ Kota & $\begin{array}{l}\text { Jumlah } \\
\text { lulusan } \\
2014\end{array}$ & $\begin{array}{l}\text { Jumlah } \\
\text { lulusan } \\
\text { 2015 }\end{array}$ \\
\hline Paser & 1.532 & 4.258 \\
\hline Kutai Barat & 1.045 & 956 \\
\hline Kutai Kertanegara & 4.125 & 4.401 \\
\hline Kutai Timur & 1.323 & 1.389 \\
\hline Berau & 687 & 1.382 \\
\hline Penajam PU & 3.589 & 3.643 \\
\hline Balikpapan & 1.252 & 4.433 \\
\hline Samarinda & & 1.228 \\
\hline Bontang & - & 194 \\
\hline Mahakam Ulu & 2014 & \\
\hline
\end{tabular}

Sumber: BPS Kaltim 2014 [4]

Lulusan SLTA di Balikpapan sebesar \pm 3.500 tiap tahun merupakan potensi besar untuk menjadi peserta didik perguruan tinggi yang ada di Balikpapan. Sedangkan total perguruan tinggi di Balikpapan ada sebanyak 11 dan Politeknik Negeri Balikpapan adalah satu - satunya Perguruan Tinggi Negeri yang ada di Balikpapan. Sehingga menjadi daya tarik yang besar bagi para calon peserta didik yang ada di Balikpapan dan daerah sekitarnya.

\section{Metoda Penelitian}

Metode yang digunakan dalam penelitian ini adalah metode deskriptif dengan menggunakan survei bertipe Cross Sectional Survey, dimaksudkan untuk melakukan terhadap fenomena tertentu dengan mengembangkan konsep dan menghimpun fakta dilapangan tetapi tidak melakukan pengujian hipotesis. Metode pengumpulan data primer dalam penelitian ini dengan menggunakan kuesioner pertanyaan tertutup dan terbuka.

Populasi dari penelitian ini adalah siswa SMA/SMK/MA di tiga kota/kabupaten provinsi Kalimantan Timur tahun ajaran 2015/2016 yaitu Balikpapan, Samarinda dan Penajam Paser Utara. 
Metode pengambilan sampelnya adalah Purposive Sampling. Purposive Sampling atau Judgment-Sampling yaitu metode pengambilan sampel yang telah terpilih dan dikategorikan menurut ciri yang dimilki oleh sampel

\section{Hasil dan Pembahasan}

1. Deskripsi profil responden

Responden penelitian ini adalah siswa SMA/SMK/MA kelas 11 tahun ajaran 2015/2016. Pengambilan data dilaksanakan tanggal 10 Juli 2016 sampai dengan 10 Agustus 2016. Jumlah responden yang menjadi sampel penelitian ini adalah sebanyak 197 responden yang tersebar di tiga kota di kalimantan timur. Yaitu Balikpapan, Samarinda dan Penajam Pasir Utara dengan rincian sebagai berikut:

Tabel 4 Sebaran Responden Penelitian

\begin{tabular}{|l|l|l|l|}
\hline Kab/kota & SMA & SMK & MA \\
\hline Balikpapan & 57 & 50 & 10 \\
\hline Samarinda & 45 & 25 & \\
\hline $\begin{array}{l}\text { Penajam } \\
\text { Paser } \\
\text { Utara }\end{array}$ & - & 10 & - \\
\hline
\end{tabular}

Secara umum, jika dilihat dari jenis sekolah responden maka gambaran rsponden tersaji dalam diagram berikut.

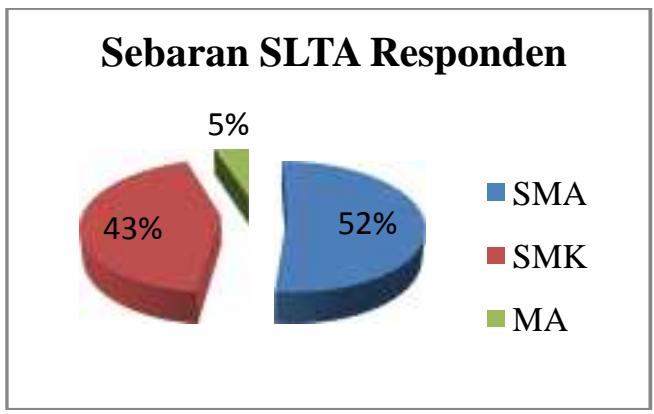

2. Rencana responden Setelah Lulus SMA/SMK/MA

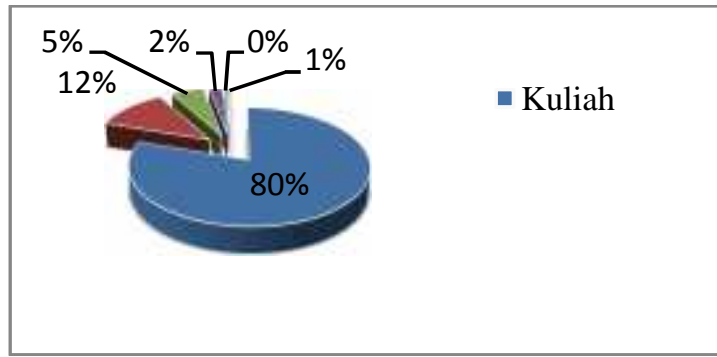

3. Kota yang menjadi tujuan utama untuk kuliah

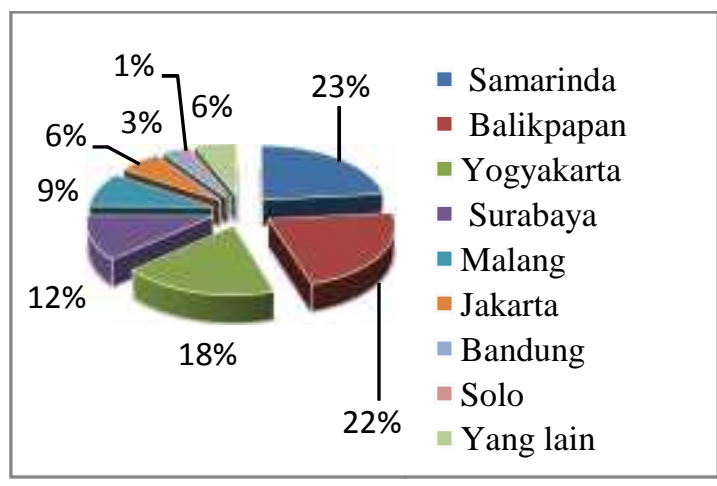

4. Bidang yang dipilih untuk melanjutkan Studi.

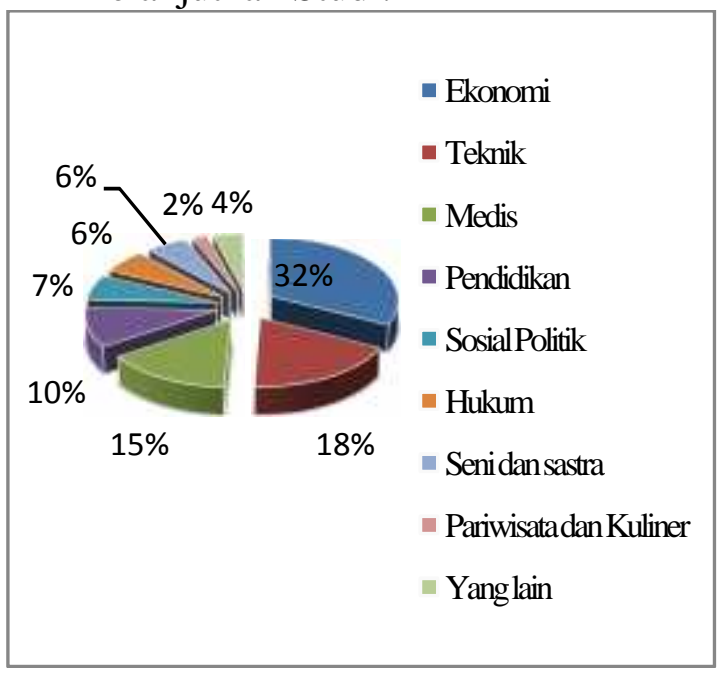

5. Hal yang mempengaruhi keputusan Siswa untuk memilih perguruan Tinggi

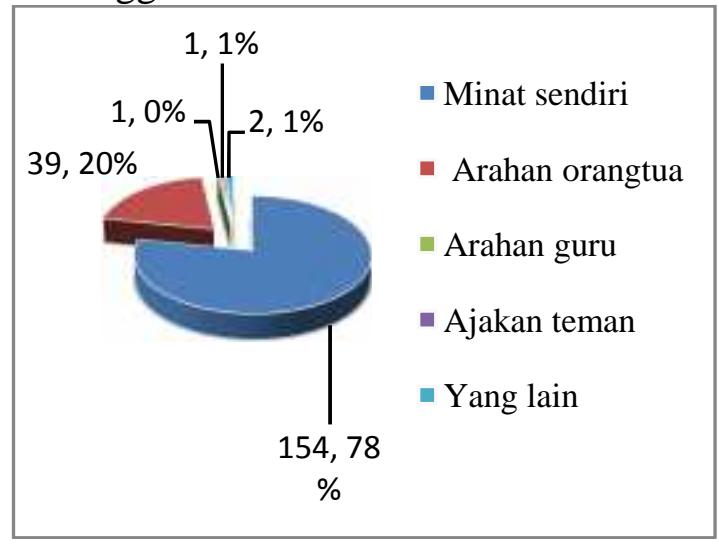

6. Perguruan Tingggi di Kalimantan Timur yang menjadi Pilihan Utama untuk Kuliah 


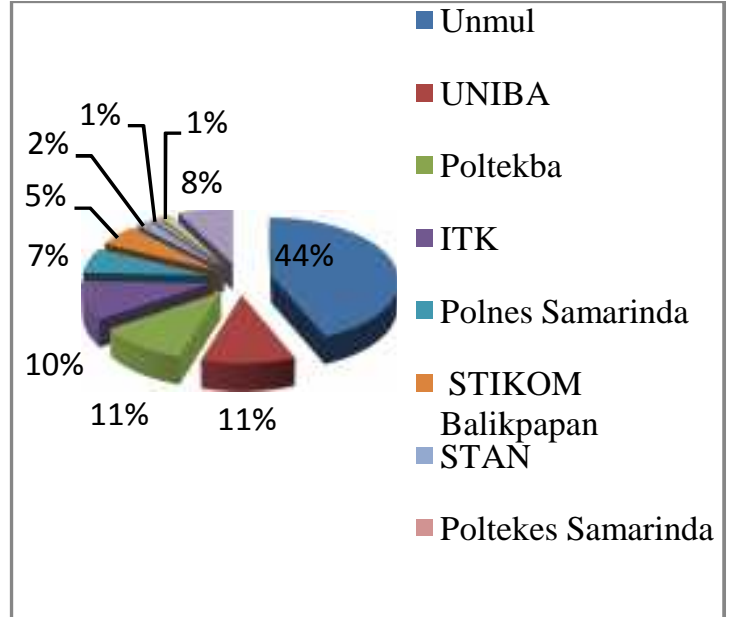

7. Program Studi di Politeknik Negeri Balikpapan yang paling Diminati

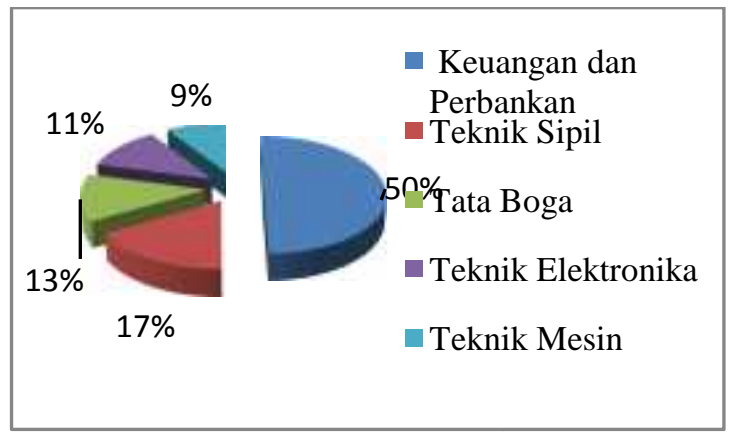

8. bidang kerja yang paling diminati

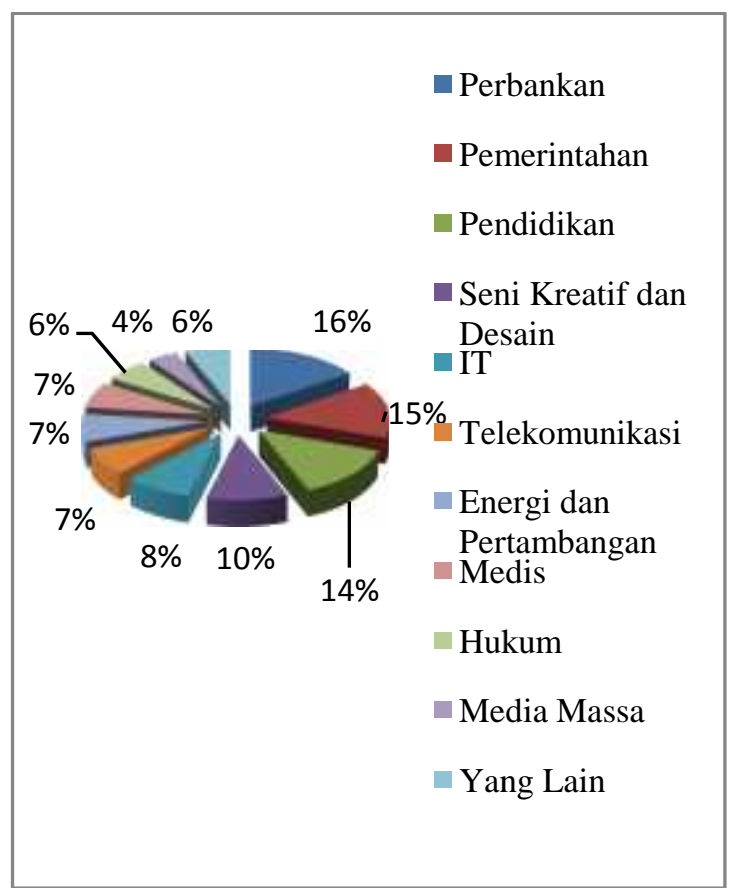

Pada survey minat bidang kerja, setiap responden diberi kesempatan memilih 3 pilihan.

\section{Kesimpulan dan Saran}

Dari rangkaian survey yang dilaksanakan, didapatkan kesimpulan sebagai berikut:

1. $80 \%$ siswa lulusan SLTA berorientasi melanjutkan ke perguruan tinggi

2. Samarinda (23\%) dan Balikpapan (22\%) adalah tujuan utama yang dipilih untuk kuliah. Selebihnya mayoritas memilih kota besar di pulau Jawa.

3. Mayoritas siswa calon lulusan SLTA berminat kuliah di bidang non rekayasa khususnya dibidang ekonomi.

4. Unmul adalah pilihan pertama jika siswa lulus SLTA, dilanjutkan Uniba dan Poltekba.

5. Program Studi yang paling diminati di Politeknik Negeri Balikpapan adalah prodi Keuangan dan Perbankan

6. Bidang kerja yang menjadi pilihan utama siswa calon lulusan SLTA adalah perbankan, pemerintahan (CPNS), dan dibidang pendidikan.

Saran dari penelitian ini adalah sebagai berikut:

1. Perlu dilakukan survey lanjutan yang dilaksanakan pada responden kelas 12, sehingga hasil responden lebih mendekati keputusan yang dipilih.

2. Perluasan sebaran responden dikota tang lain di Kalimantan Timur perlu dilakukan untuk memperbesar representasi subyek penelitian.

3. Politeknik perlu melakukan sosialisasi dan promosi yang lebih baik untuk lebih mengenalkan keberadaannya sebagai sebuah perguruan tinggi negeri di Kalimantan Timur.

4. Politeknik perlu melakukan pengembangan program studi dibidang non rekayasa untuk menjaring potensi calon lulusan yang cukup besar di Kalimantan Timur. 


\section{Daftar Pustaka}

[1]Balikpapan dalam Angka ( Balikpapan in Figure) .2013. Balikpapan: Badan Perencanaan Pembangunan Daerah dan Badan Pusat Statistik Kota Balikpapan

[2]Badan Pusat Statistik Kalimantan Timur.(2015) Banyaknya Murid SMU/MA yang Lulus (UAN) Menurut Kabupaten/Kota, 2014/2015 . 2015. (online).(http://kaltim.bps.go.id/linkTabelSt atis/view/id/258\#accordion-daftar-subjek3). Diakses tanggal 12 Oktober 2016.

[3]Berita Resmi Statistik BPS Kalimantan Timur. Keadaan Tenaga Kerja Kalimantan Timur *)Februari 2014. No.22/05/64/Th.XVII, 5 Mei 2014

[4]Berita Resmi Statistik BPS Kalimantan Timur. Pertumbuhan Ekonomi Kalimantan Timur Tahun 2014. No. 010/02/64/Th.XVIII, 5 Februari 2015
[5]Gantini, Tiur dan Jayalaksana, Yenny Merlin.2012.Survey dan Analisis Perkembangan (Trend) Kebutuhan Kompetensi Tenaga Kerja Teknologi Informasi di Pasar Kerja Industri Indonesia.Pelaksanaan Survey: Januari Mei 2012.

[6]Manurung, Mandala.2004. Uang, Perbankan, dan Ekonomi Moneter (Kajian Kontekstual Indonesia).Jakarta: Lembaga Penerbit UI

[7]Sugiyono. 2011. Metode Penelitian Kuantitatif Kualitatif dan R \& D. Bandung: Alfabeta.

[8] Statistik Perbankan Indonesia (Indonesian Banking Statistics). Vol: 12 No. 12, November 2014.(online). (http://www.ojk.go.id/data-statistikperbankan-indonesia). Diakses tanggal 10 Februari 2015. 